\title{
Chemical Disinfestation for Sowing and in Vitro Re-cultivation of Orchids and its Influence on the Seedlings Nutrition
}

\author{
Andréia Aline Fontes \\ Soil Science department, Federal University of Viçosa, Avenue Peter Henry Rolfs, ZIP CODE \\ 36570-900, Viçosa, Minas Gerais, Brazil. alinefontes@yahoo.com.br \\ Victor Hugo Alvarez V.
}

Soil Science department, Federal University of Viçosa, Avenue Peter Henry Rolfs, ZIP CODE 36570-900, Viçosa, Minas Gerais, Brazil.vhva@ufv.br

Sarah Vieira Novais (Corresponding author)

Soil Science department, ESALQ/São Paulo University, Avenue Pádua Dias, 11, ZIP CODE 13418-900, Piracicaba, São Paulo, Brazil. sarahnovais@usp.br

Wagner Campos Otoni

Plant Physiology department, Federal University of Viçosa, Avenue Peter Henry Rolfs, ZIP CODE 36570-900, Viçosa, Minas Gerais, Brazil. wotoni@ufv.br

\section{André Ferreira Santos}

Soil Science department, Federal University of Viçosa, Avenue Peter Henry Rolfs, ZIP CODE 36570-900, Viçosa, Minas Gerais, Brazil.s.andreferreira@gmail.com

\section{Roberto Ferreira Novais}

Federal University of Viçosa, Institute of Agricultural Sciences, Campus Rio Paranaíba. Rod.MG-230, km 7. ZIP CODE 38810-000, Rio Paranaíba, Minas Gerais, Brazil. rfnovais@ufv.br 
Received: October 4, 2017

doi:10.5296/jas.v5i4.12099
Accepted: October 19, 2017 Published: November 3, 2017

URL: https://doi.org/10.5296/jas.v5i4.12099

\begin{abstract}
The use of a commercial bleach solution (CB) for in vitro propagation of orchids has proven to be an efficient technique and an alternative to the use of the autoclave and laminar flow chamber (LFC). The aim of this study was to evaluate the use of CB in disinfestation of culture media (CM) for seeding and for re-cultivation of orchid plantlets and its effect in different types of flasks and on the nutritional state of the plantlets. In the seeding experiment, seeds of Laelia tenebrosa Rolfe were used, with evaluation of three types of flasks; five concentrations of $\mathrm{CB}$ applied to the $\mathrm{CM}$ of 2, 5, 10, 20 and $40 \mathrm{~mL} \mathrm{~L}^{-1}$ and the control treatment. In the re-cultivation experiment, Cattleya kerri Brieger \& Bicalho plantlets were used. The rates of $\mathrm{CB}$ added to the $\mathrm{CM}$ were $2,5,10,20,30,35$ and $38 \mathrm{~mL} \mathrm{~L}^{-1}$ in polypropylene containers, and the rates sprayed on the plantlets at re-cultivation were $5,12.5$, $25,50,75,87.5$ and $95 \mathrm{~mL} \mathrm{~L}^{-1}$. The proportion of germinated seeds and the dry matter weight of the protocorms were greater in the control treatment. The increasing rates of $\mathrm{CB}$ added to the CM had worse results for germination in glass flasks. In re-cultivation, there was no significant difference in the growth of the plantlets between the autoclaved flasks and those disinfested in $\mathrm{CB}$.
\end{abstract}

Keymessage: Both orchid seeding and re-cultivation of seedlings can be carried out entirely and efficiently without the use of an autoclave and laminar flow chamber, using chemical disinfection with commercial bleach.

Keywords: Orquidaceae, bleach, micropropagation.

\title{
1. Introduction
}

The orchids have highlighted acceptance on the ornamental flowers market (Kishor et al. 2006; Ferreira et al. 2016) and to meet the growing commercial demand, the main way to produce their seedlings is through in vitro propagation (Rego-Oliveira and Faria 2005; Sharma 2016), a method that provides a large number of seedlings, in reduced space and time, economically viable.

In the commercial production of in vitro seedlings, the culture media used provide sugars and nutrients necessary for germination and seedlings growth and development, components that allow the easy proliferation of fungi and bacteria (Lima and Moraes 2006; Torres et al. 2016), which makes the contamination of the culture medium one of the biggest problems.

With the goal of obtaining seedlings free from microorganisms, the tissue culture laboratories invest in expensive equipment, such as the autoclave and laminar flow chamber (LFC). For small producers and collectors of orchids, these equipments are not readily available, due to the high cost. However, researchers have sought ways to simplify this in vitro cultivation technique such as the use of pressure cooker (Pierik 1997), microwave oven (Teixeira et al. 2005; Venturieri et al. 2013) and chemicals disinfectants for sterilization of culture medium (Anand et al. 2013; Torres et al. 2016; Ray et al. 2017). 
The most commonly used disinfectants are the ethanol and the compounds based on $\mathrm{Cl}$, such as sodium hypochlorite $(\mathrm{NaClO})$ and calcium hypochlorite $\left(\mathrm{Ca}(\mathrm{ClO})_{2}\right)$ (Donini et al. 2005; Braga et al. 2015; Pereira et al. 2015). The employment of $\mathrm{NaClO}$, having as a source commercial bleach (CB) in the disinfestation of seeds and culture media, proves to be an efficient and low cost method and the product easy to purchase (Rodrigues et al. 2012).

Yanagawa et al. (1995) tested the disinfestation of the culture medium with CB for transplanting explants of Bletilla striata and concluded that $0.105 \mathrm{~g} \mathrm{~L}^{-1}$ of $\mathrm{NaClO}\left(3.57 \mathrm{~mL} \mathrm{~L}^{-1}\right.$ of $\left.\mathrm{CB}\right)$, applied to the culture medium, and, $5.24 \mathrm{~g} \mathrm{~L}^{-1}$ of $\mathrm{NaClO}\left(178 \mathrm{~mL} \mathrm{~L}^{-1}\right.$ of $\left.\mathrm{CB}\right)$, sprayed on the seedlings, did not cause plant growth loss. Alvarez-Pardo et al. (2006), studying the influence of $\mathrm{NaClO}$ on orchids seed germination, using concentrations of 4.2 and $8.4 \mathrm{~g} \mathrm{~L}^{-1}$ and exposure times from 5 to $60 \mathrm{~min}$, observed reduction in germination with the increase of concentration and the seeds exposure time to the disinfectant. The treatment with $4.2 \mathrm{~g} \mathrm{~L}^{-1}$ of $\mathrm{NaClO}\left(143 \mathrm{~mL} \mathrm{~L}^{-1}\right.$ of CB) for 5 min was, for most species, more effective in controlling contamination, with $87 \%$ of germination of the seeds. Rodrigues et al. (2013) observed a negative effect on germination with increasing concentration of $\mathrm{NaClO}$, which ranged from 50 to $250 \mathrm{ml} \mathrm{L}^{-1}$ of $\mathrm{CB}$. Such effect was assigned to the disinfectant toxicity. On the other hand, the lowest concentration of $\mathrm{NaClO}$ was efficient in microbial control, as well as having promoted higher growth of seedlings, unlike the control, carried out in LFC, without using disinfectant.

Another aspect to be considered on the use of chemical disinfectants in seeds and seedlings concerns the effect of $\mathrm{NaClO}$ on plants nutrition. However, there were no references comprising such information. Thus, the aims of this study were to evaluate the use of $\mathrm{NaClO}$ in the form of $\mathrm{CB}$, on the disinfestation of seeds and culture medium for sowing and in-vitro re-cultivation orchids species, in different types of flasks, and its effect on the seedlings nutritional state.

\section{Material and Methods}

Two experiments were carried out in the Laboratory of Experimental Morphogenesis of the Department of Plant Biology from Federal University of Viçosa (Brazil): one assessed the effect of $\mathrm{NaClO}$ on sowing phases and the other on re-cultivation phases.

\subsection{Sowing Experiment}

This experiment consisted of a factorial [3 $(5+1)]$, with three types of flasks: a glass with a capacity for $340 \mathrm{~mL}\left(\mathrm{Gl}_{340}\right)$, and two plastic (polypropylene), with $140\left(\mathrm{Po}_{140}\right)$ and $340 \mathrm{~mL}$ $\left(\mathrm{Po}_{340}\right)$; five concentrations of commercial bleach $(\mathrm{CB})$ - Candura ${ }^{\circledR}$ applied to the culture medium, 2; 5; 10; 20 and $40 \mathrm{~mL} \mathrm{~L}^{-1}$ (with $40 \mathrm{~mL}$ of culture medium per flask), equivalent to 59; 147; 294; 589 and $1176 \mathrm{mg} \mathrm{L}^{-1}$ of $\mathrm{NaClO}$, respectively. The control treatment was carried out by using autoclaving media and seeding under conditions of LFC, without the use of the chemical disinfectant, in the three types of flasks. Seeds of Laelia tenebrosa Rolfe were used. The experiment was arranged according to a randomized block design with five replications.

Analysis of the CB used was performed, through the method of Mohr (Vogel 1992), and this showed $29.4 \mathrm{~g} \mathrm{~L}^{-1}$ of $\mathrm{NaClO}$. The glassware used for the preparation of the culture medium was rinsed with CB. The culture medium used was the supply medium (S) (Santos, 2009), 
consisting of $5 \mathrm{~g} \mathrm{~L}^{-1}$ of fertilizer salts B\&G Orchidées ${ }^{\circledR}$, a "Mixed Mineral Fertilizer", with total nutrient contents: $8.00 \% \mathrm{~N}$ (soluble in $\mathrm{H}_{2} \mathrm{O}$ ), $11.0 \% \mathrm{P}_{2} \mathrm{O}_{5}, 7.00 \% \mathrm{~K}_{2} \mathrm{O}$ (soluble in $\mathrm{H}_{2} \mathrm{O}$ ), $7.52 \% \mathrm{Ca}, 1.25 \% \mathrm{Mg}, 3.76 \% \mathrm{~S}, 0.09 \% \mathrm{~B}, 0.05 \% \mathrm{Cu}, 0.56 \% \mathrm{Fe}, 0.20 \% \mathrm{Mn}, 0.007 \%$ Mo, and $0.35 \% \mathrm{Zn}$ (http://www.begflores.com.br/), $7 \mathrm{~g} \mathrm{~L}^{-1}$ of agar (Merck $\left.{ }^{\circledR}\right), 40 \mathrm{~g} \mathrm{~L}^{-1}$ of sucrose and $2 \mathrm{~g} \mathrm{~L}^{-1}$ of activated charcoal $\left(\operatorname{Vetec}^{\circledR}\right)$.

The culture medium was prepared in a microwave oven, used to dissolve the salts, as well as to melt the agar. Subsequently, the medium was homogenized and the $\mathrm{CB}$ added to the culture medium still warm $\left(60^{\circ} \mathrm{C}\right)$, then the $\mathrm{pH}$ was adjusted to $5.7 .40 \mathrm{~mL}$ of culture medium in each flask was added. The plastic flasks were covered and the glass ones had the caps of rigid polypropylene screwed, immediately after addition of the medium.

The sowing was performed one day after the preparation of culture medium. For this, we used a disposable syringe with a capacity of $20 \mathrm{~mL}$, where the seeds and a solution of CB 100 $\mathrm{mL} \mathrm{L}^{-1}\left(2.9 \mathrm{~g} \mathrm{~L}^{-1}\right.$ of $\left.\mathrm{NaClO}\right)$ remained in contact for $10 \mathrm{~min}$. Then the $\mathrm{CB}$ was removed and an autoclaved water was sucked out for the seeds washing. Subsequently, this suspension of seeds was transferred to a beaker $(250 \mathrm{~mL})$ containing a magnetic, both sterilized with $\mathrm{CB}$, and was kept in shaking under LFC, in order to keep it free from contamination, simulating a sterile environment inside a syringe. It was added up, then, $1 \mathrm{~mL}$ of this suspension per flask with the aid of an automatic pipette, so that the number of seeds per flask were similar. Immediately after the sowing, the edges of the caps and flasks were protected with transparent film of polyvinyl chloride (PVC). For the control treatments, in plastic flasks, the culture medium was sterilized and subsequently poured into flasks inside the LFC; For the control treatments, in glass flask, the culture medium was autoclaved inside the own flasks. The seeds used in control treatments were disinfected with the same solution of CB $(100 \mathrm{~mL}$ $\mathrm{L}^{-1}$ used in other treatments. After sowing, the flasks were kept in a growth room with temperature of $27^{\circ} \mathrm{C}$, irradiation of $48 \mu \mathrm{mol} \mathrm{m}^{-2} \mathrm{~s}^{-1}$ and photoperiod of $16 \mathrm{~h}$.

The experimental unit was composed of a flask containing, on average, 590 seeds of Laelia tenebrosa Rolfe. The seedlings were harvested after four months of sowing for evaluation of the proportion of oxidized seeds (seeds and protocorms who had brown color) and germinated seeds (sum of oxidized seeds and the developed seedlings), and the number and the yield of fresh and dry matter of seedlings. The assessment regarding the contamination by fungi and bacteria was performed since the sowing.

\subsection{Re-cultivation Experiment (replanting)}

For the second experiment (re-cultivation), Cattleya kerri seedlings were growing for six months in glass flasks containing the medium S. For the transplanting, the seedlings exhibited, on average, height and fresh weight of $0.5 \mathrm{~cm}$ and $40 \mathrm{mg}$, respectively. Solutions containing $\mathrm{CB}$ were added to the culture media during the preparation of the same, and sprayed on the plants, during the re-cultivation. The seedlings re-cultivation occurred one day after the medium preparation.

The treatments for the two factors under study, followed the matrix Box Berard increased (3), modified in accordance with Leite (1984), and with three additional treatments. 


\section{MInstitute ${ }_{\text {Int" }}^{\text {Macrothink }}$}

The concentrations of $\mathrm{CB}$ added (homogenized) to the culture medium were: $2 ; 5 ; 10 ; 20 ; 30$; 35 e $38 \mathrm{~mL} \mathrm{~L}^{-1}$, equivalent to, respectively, 59; 147; 294; 589; 882; 1029 and $1117 \mathrm{mg} \mathrm{L}^{-1}$ of $\mathrm{NaClO}$; and, the concentrations of $\mathrm{CB}$ sprayed on the seedlings (transplanted) and on the internal part of the flask caps, were: $5,12,5,25,50,75,87,5$ and $95 \mathrm{~mL} \mathrm{~L}^{-1}(147,368,735$, $1470,2205,2573$ and $2793 \mathrm{mg} \mathrm{L}^{-1}$ of $\mathrm{NaClO}$, respectively). The volume sprayed on the flask, of the disinfectant solutions, in the different concentrations was $0.5 \mathrm{~mL}$. The additional treatments were: the control and two combinations of $\mathrm{CB}$ added to the culture medium and sprayed at concentrations of 2 and 95 and 38 and $5 \mathrm{~mL} \mathrm{~L}^{-1}$, respectively. Immediately after such application, the flasks were closed and the edges protected with transparent film of polyvinyl chloride (PVC). In the control treatment, the medium was autoclaved and subsequently poured into plastic flask in LFC, where the seedlings transplanting were also done. After transplanting, the flasks were kept in a growth room under the conditions already mentioned.

This experiment was conducted in a completely randomized blocks with six replications. The experimental unit consisted of a plastic flask of polypropylene with $140 \mathrm{~mL}$ capacity, containing $35 \mathrm{~mL}$ of culture medium and 10 seedlings. The flasks were assessed frequently regarding contamination by fungi and bacteria and, after five months, the experiment was collected and taken the following measurements: height of seedlings, number of sprouts, leaves and roots, dry matter of aerial parts and of roots and ratio between dry matter of roots and shoots. The seedlings were taken to a forced air circulation oven, at $60{ }^{\circ} \mathrm{C}$ until constant weight, ground in a mortar and subjected to sulfuric and to nitric-perchloric digestion for determination of concentrations of $\mathrm{N}$ and of $\mathrm{P}, \mathrm{K}, \mathrm{Ca}, \mathrm{Mg}, \mathrm{S}, \mathrm{Fe}, \mathrm{Zn}, \mathrm{Mn}, \mathrm{B}, \mathrm{Mo}$ and $\mathrm{Cu}$, respectively. The total $\mathrm{N}$ was determined by Kjeldahl method (Jackson 2005) and the others, by inductively coupled plasma emission spectrometry. To obtain the quantity of dry matter enough for the nutritional analyzes, the repetitions were analyzed two by two, totaling three repetitions for these analyzes.

\subsection{Statistics}

The data obtained were subjected to analysis of variance and were later tested by orthogonal contrasts (Nogueira 2004).

Sowing experiment: Response curves were adjusted as a function of concentrations of CB for each type of flask used.

Re-cultivation experiment:. Response surfaces for the study variables were adjusted, depending on the concentrations of $\mathrm{CB}$ added to the culture medium and sprayed on the seedlings.

\section{Results and Discussion}

\subsection{Sowing Experiment}

The disinfestation of culture media with commercial bleach (CB) was shown to be effective in contamination control. The number of flasks contaminated with the medium treated with $\mathrm{CB}$ was lower when compared to the control treatment (media autoclaving and sowing in 


\section{Macrothink

LFC). Out of the 75 flasks disinfected with CB, only one was contaminated; of the 15 flasks that received autoclaved media, three were contaminated. Despite the low contamination, the use of chemical disinfectant showed to be phytotoxic to the germination of Laelia tenebrosa Rolfe seeds.

The proportion of germinated seeds and formed seedlings as well as the yield of fresh and dry matter were statistically higher in the control treatment, when used autoclave (Figure 1). On average, in these treatments $85 \%$ germination was obtained, whereas in desinfested with the lowest concentration of CB only $69 \%$ of seeds germinated (Figure 1b). Yanagawa et al. (1995) were successful in the disinfestation of orchid seeds with concentration of $5.24 \mathrm{~g} \mathrm{~L}^{-1}$ of $\mathrm{NaClO}$ (178 mL L-1 of CB) sprayed on the seeds. With the species Bletilla striata, Cattleya loddigessi, Habenaria radiata and hybrids from the genera Phalaenopsis and Dendrobium, these authors obtained $100 \%$ of germination and the culture medium did not exhibit any contamination.

Increasing the concentration of $\mathrm{CB}$ added to the culture medium only caused a toxic effect on the seeds and protocorm in glass flasks. In the plastic flasks there was no difference in the percentage of germination and yield of fresh and dry weight of plant tissue compared to the concentrations added (Figure 1). This is probably due to the lower loss of $\mathrm{Cl}$ by volatilization in glass flasks, creating an internal atmosphere with the CB permanence for a longer time. The type of cap sealing on plastic flasks did not limit gas exchange as in glass flasks with rigid polypropylene screwed caps. In the former, there was no total hermetic sealing where the caps are only fit over the pots. Thus, due to the higher gas exchange, the increase of CB concentration in the medium did not alter the protocorms growth and development in plastic flasks.

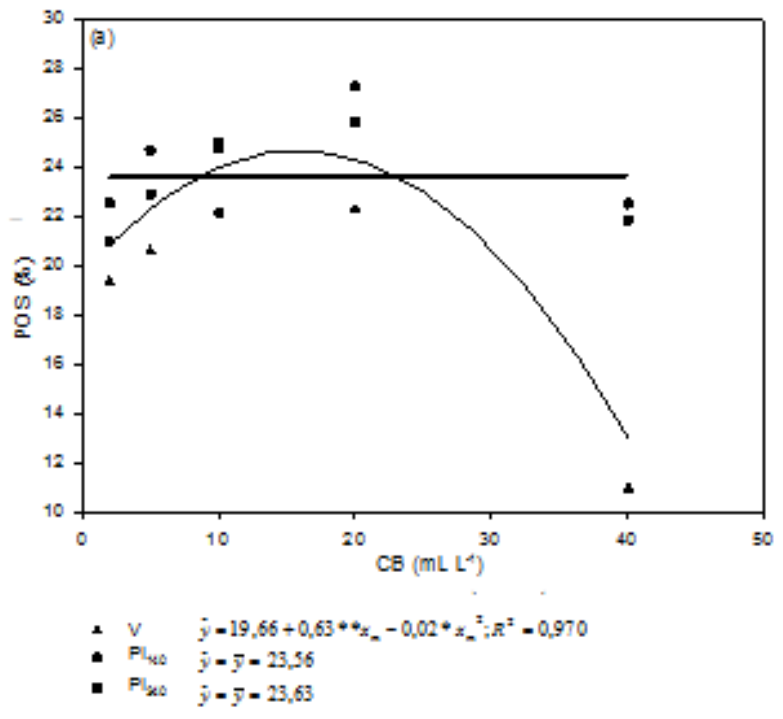




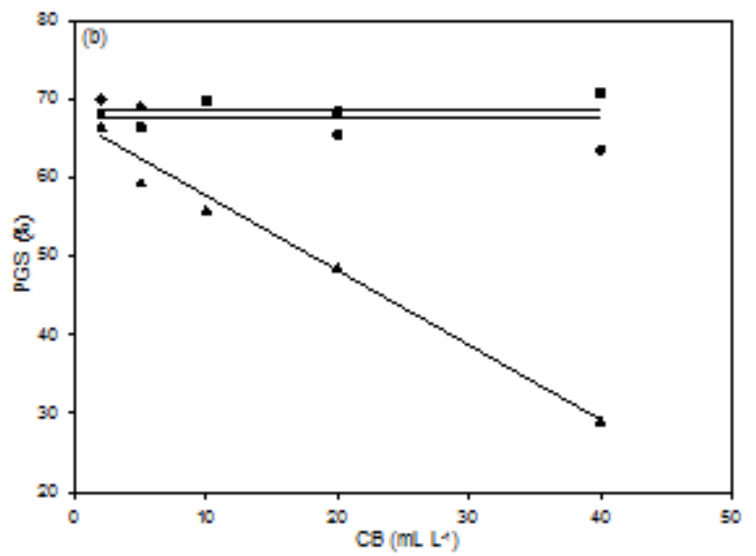

* V $\quad y=67,14-0,95^{*} \alpha_{n}, R^{2}=0,985$

- Pliso $y=\bar{y}=67,60$

- Plike $y=y=68,64$

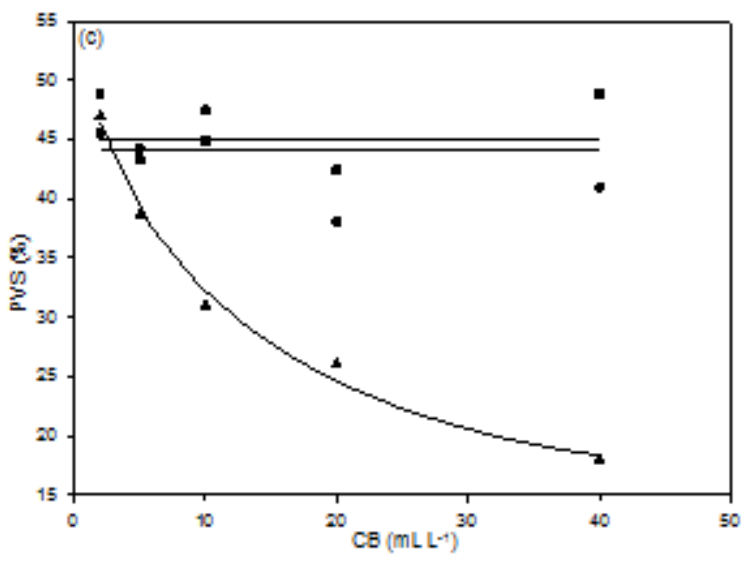

- v $\quad \hat{y}-61,22+0,76^{\circ} x_{m}-11,59 x_{m}{ }^{07} ; R^{2}=0,991$

- Proso $\hat{y}=y-44,04$

- $P_{\text {MO }} \hat{y}=y-45,02$

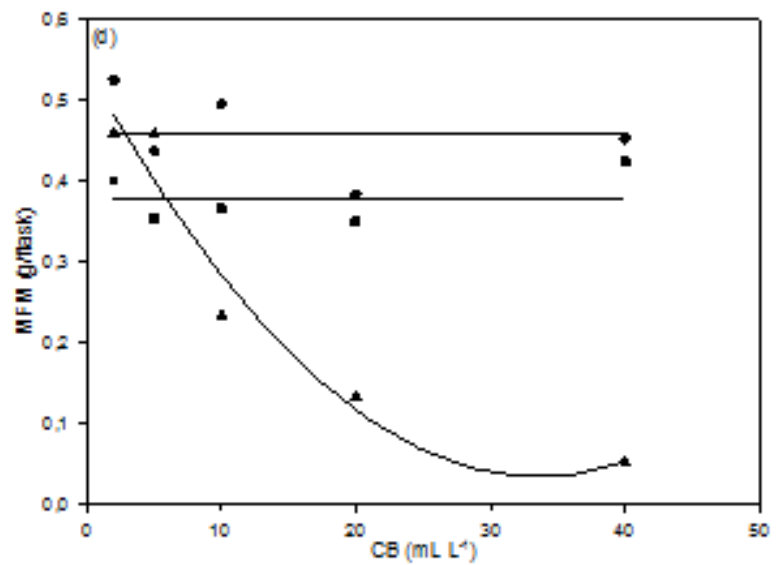

* v y $=0,5406-0,0302 * 4 x_{m}+0,0005^{*} x_{-}{ }^{2} ; R^{2}=0,95$

- P., $y=0-0,4588$

- Ris $\hat{y}=y-0,3790$ 


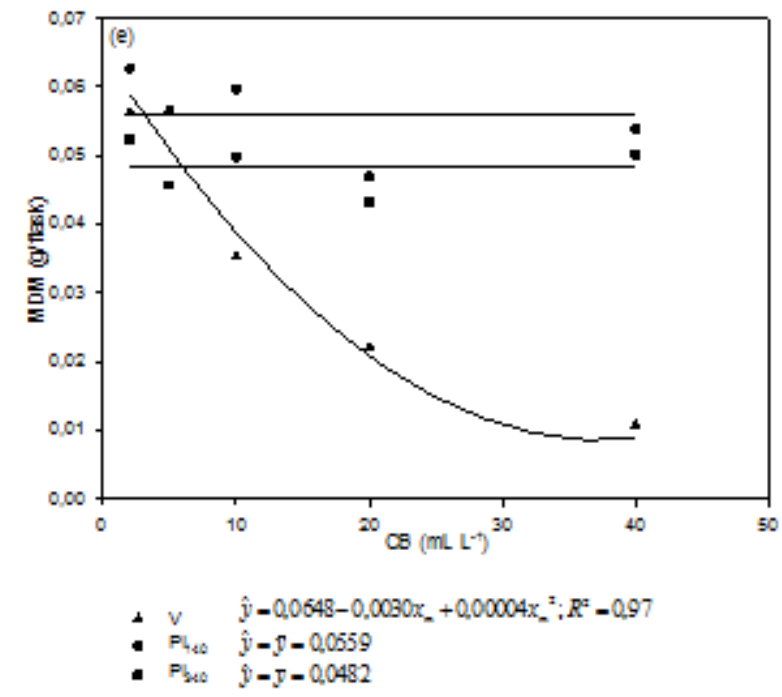

Figure 1. Effect of the commercial bleach (CB) doses added to the culture medium in different flasks on the proportion of oxidized seeds - POS (a), proportion of germinated seed - PGS (b), proportion of viable seedlings - PVS (c), mass of fresh matter - MFM (d) and mass of dry matter - MDM (e) of Laelia tenebrosa Rolfe at four months [Control treatments in the glass vial $(\mathbf{\Delta})$ and in the plastic bottles with capacities of $140 \mathrm{~mL}(\mathbf{O})$ and $340 \mathrm{~mL}(\mathbf{\square})$.

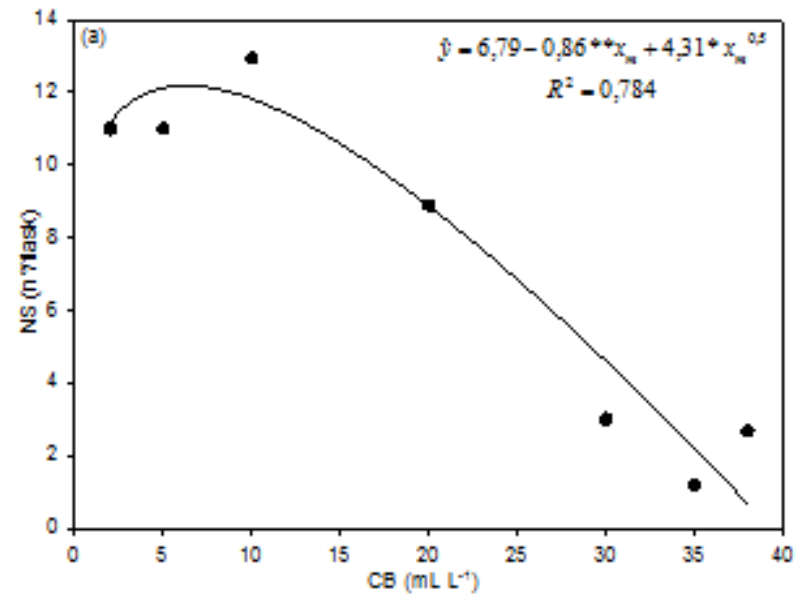



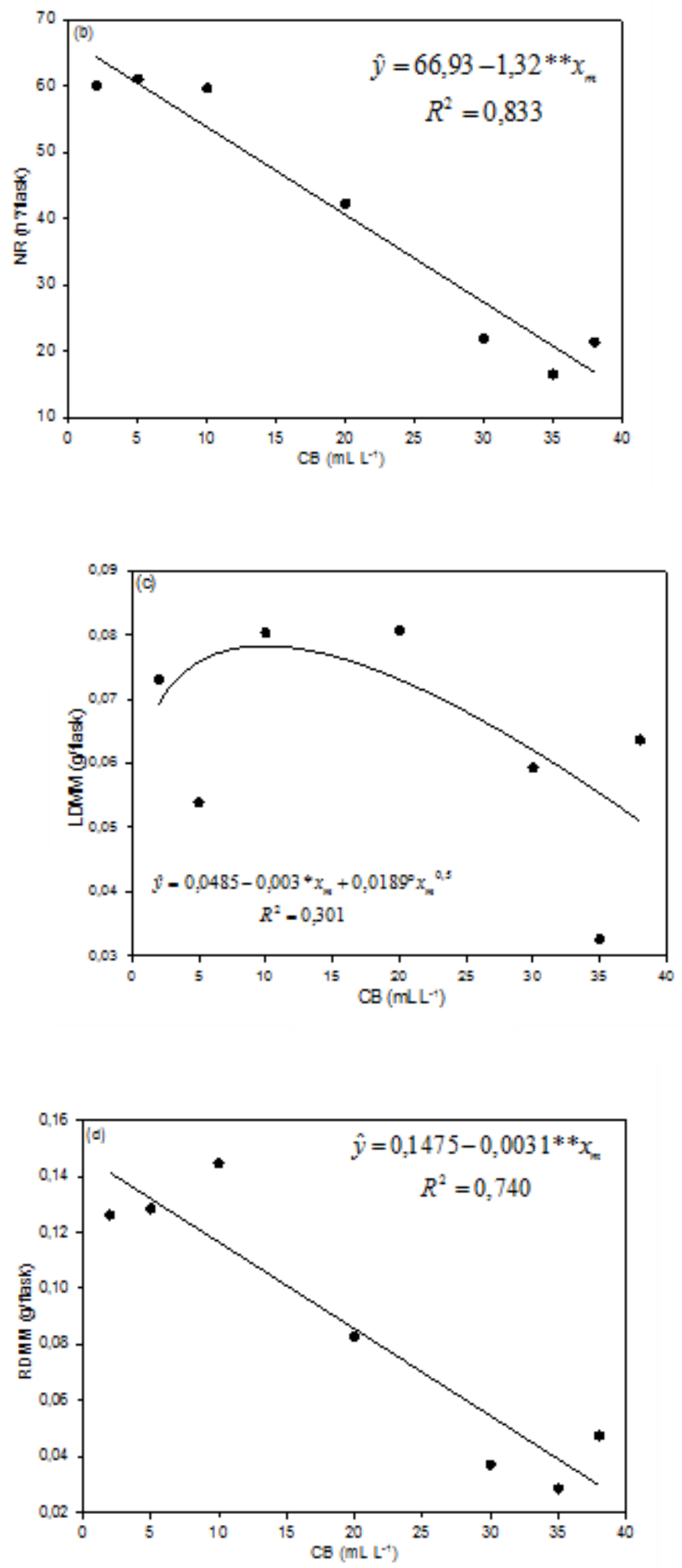


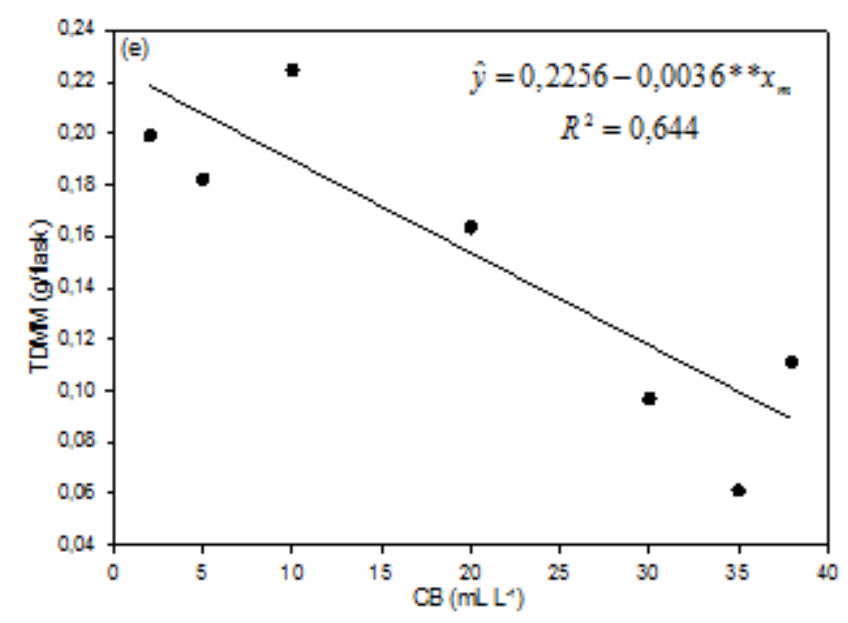

Figure 2. Number of shoots - NS (a), number of roots - NR (b), leaf dry matter mass - LDMM (c), root dry matter mass - RDMM (d) and total dry matter mass - TDMM (e) from Cattleya kerri Brieger and Bicalho per vial in response to increasing doses of commercial bleach $(\mathrm{CB})$ added to the culture medium and to mean doses of CB sprayed on the seedlings after five months of re-cultivation.

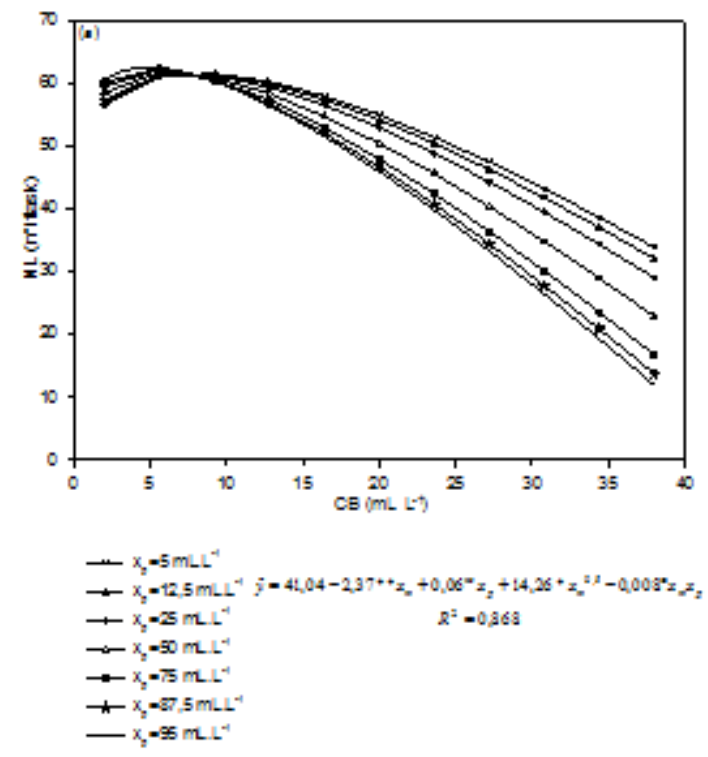




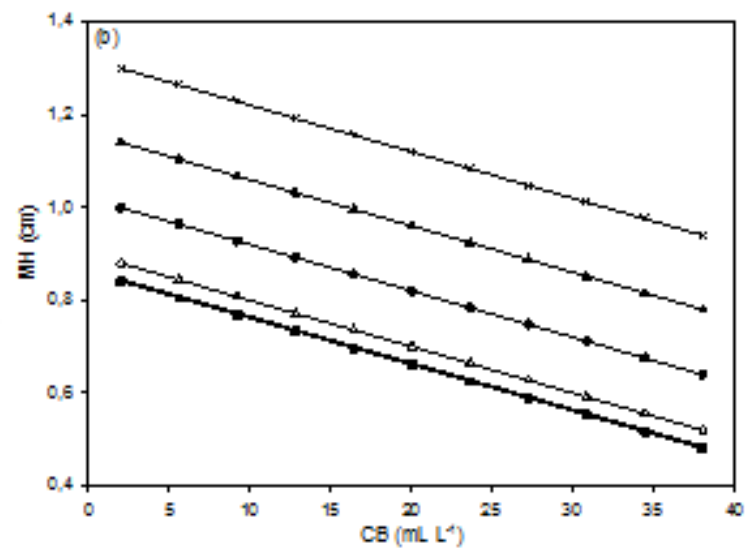

$\rightarrow-x_{0}=5 \mathrm{~mL}$

$\rightarrow x_{0}=12.5 \mathrm{mLL} \quad \hat{y}=1,67-0,01^{* 4} x_{\alpha}+0,01^{*} x_{z}-0,18^{* 4} x_{z}, 7$

$\rightarrow x_{0}=25 \mathrm{~mL}$

$R^{2}=0,802$

$\rightarrow x_{0}=50 \mathrm{~mL}$

$\rightarrow x_{6}=75 ; 87,5$ e $95 \mathrm{mLL}$

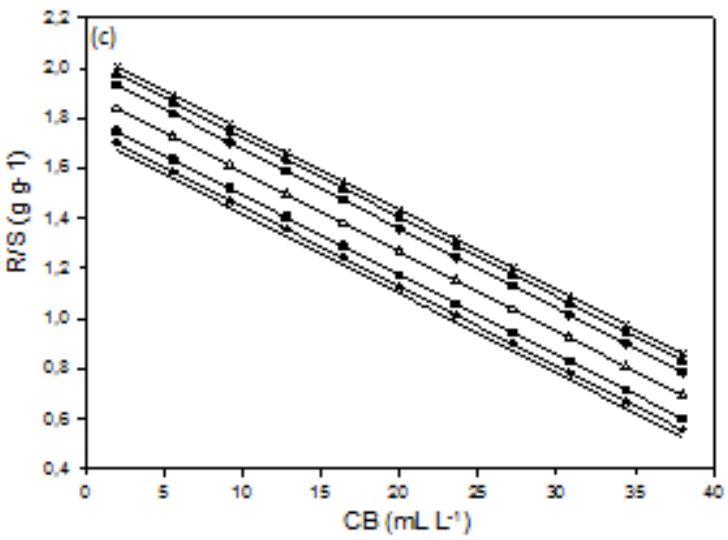

$\pi-x_{z}=5 \mathrm{mLL}^{-4}$

$+x_{x}=12.5 \mathrm{mLL}^{-1} \quad \hat{y}=2,0887-0,0318 * 4 x_{m}-0,0037^{\circ} x_{z}$

$\rightarrow x_{z}=50 \mathrm{mLL}^{-1} \quad R^{2}=0,747$

$\rightarrow-x_{z}=75 \mathrm{mLL}$

$\rightarrow x-87.5 \mathrm{~mL} \mathrm{~L}$

$-x,-95 \mathrm{mLL}$

Figure 3. Cuts on the leaf number response surfaces - NL (a), mean height - MH (b) and rate between root and shoot dry matter yield - Cattleya kerri Brieger's R/S Bicalho (c) per flask as a variable of increasing doses of commercial bleach $(\mathrm{CB})$ added to the culture medium $(\mathrm{Xm})$ and doses of $\mathrm{CB}$ sprayed on the seedlings during the re-cultivation $(\mathrm{Xp})$ 
The results obtained highlight the importance of the type of flask used and, therefore, the internal atmosphere of the same on the performance of the cultures and their relationship with the disinfestation effectiveness by CB. At the tissue culture of several plants species the morphogennic responses have been associated to the quality of the internal culture and the free volume of air (head space) in the flasks, the type and size of flasks and the type of seal (Demeester et al. 1995; Chen 2004; Marino and Berardi 2004; Zobayed 2006; Gonçalves et al. 2008; Ribeiro et al. 2009; Rodrigues et al. 2012; Pinheiro et al. 2013; Srivastava et al. 2016; Batista et al. 2017).

In glass flasks, the proportion of seeds oxidized presented a quadratic response to the CB concentration effect, with increased oxidation until the estimated concentration of $15.75 \mathrm{~mL}$ $\mathrm{L}^{-1}$, with subsequent decrease as the concentration is increased (Figure 1a). The lowest seed oxidation originating in this concentration was due to the lowest number of germinated seeds, $52 \%$. Increasing the concentration of $\mathrm{CB}$ has a linear negative effect on germination in glass flasks; with the highest concentration of $\mathrm{CB}\left(40 \mathrm{~m} \mathrm{~L}^{-1}\right)$ only $29 \%$ of germination was obtained (Figure 1b).

Rodrigues et al. (2011), using concentrations ranging between 1.2 and $4.800 \mathrm{mg} \mathrm{L}^{-1}$ of $\mathrm{NaClO}\left(0.04\right.$ and $\left.163 \mathrm{~mL} \mathrm{~L}^{-1} \mathrm{CB}\right)$, found positive results for the Cattleya intermedia germination with the use of $\mathrm{CB}$ at lower concentrations. According to these authors, $\mathrm{NaClO}$ was shown to be effective in contamination control; however, increasing the concentration reduced the seed germination.

Increasing concentrations of $\mathrm{CB}$ resulted in a decrease in the proportion of viable seedlings for re-cultivation and the yield of fresh and dry matter of Laelia tenebrosa Rolfe. The lowest and highest concentrations of CB (2 and $\left.40 \mathrm{~mL} \mathrm{~L}^{-1}\right)$ provided, respectively, 47 and $18 \%$ of viable seedlings, 0.46 and $0.053 \mathrm{~g} /$ flask of fresh matter and 56 and $11 \mathrm{mg} /$ flask of dry matter, respectively (Figure 1c, 1d, 1e).

Regarding the plastic flasks of different sizes, there was no significant difference for proportion of seeds oxidized, germinated seeds and viable seedlings. Only for yield of fresh and dry matter of seedlings a significant difference was observed. In the $140 \mathrm{~mL}$ plastic flasks it was obtained, on average, respectively, 80 and $10 \mathrm{mg} / \mathrm{flask}$ of fresh and dry matter more than in $340 \mathrm{~mL}$ plastic flasks. These results are similar to those observed by Moraes et al. (2010) for the seedlings of Dendrobium nobile Lind. cultivated in vitro, which obtained higher yield of fresh and dry matter in $100 \mathrm{~mL}$ flasks, when compared to those of 200 and $400 \mathrm{~mL}$. According to Pierik (1987), seedlings grown in larger flasks have more exposed surfaces of culture medium, and the seedlings subjected to a drier environment, due to a more intense access to light and, therefore, heat. This author also stresses that plants in larger flasks are more susceptible to contamination comparing to smaller ones.

The proportion of oxidized seeds in glass flasks was higher in the control treatment $(12.7 \%)$ in relation to the lowest concentration of $\mathrm{CB}\left(2 \mathrm{~mL} \mathrm{~L}^{-1}\right)$. For the140 $\mathrm{mL}$ plastic flasks no significant difference was observed in the proportion of oxidized seeds between the control treatment and the lowest concentration of $\mathrm{CB}$; those with $340 \mathrm{~mL}$, the oxidation was higher 
with the use of CB (Figure 1a). This variation on the seed oxidation is due to, in the case of glass flasks, probably the activated charcoal, which adsorbs toxic compounds, such as phenols, produced by plants, reducing the seeds and the protocorms oxidation (Thomas 2008; Rodrigues et al. 2013). In the control treatment, the culture medium was autoclaved inside the flasks and, after its cooling, there was a small decantation of the activated charcoal in the bottom of the flask. Therefore, the surface that was in contact with the seeds had less activated charcoal than the media that were in plastic flasks, since they were autoclaved in an Erlenmeyer flask and the medium was poured into flasks in LFC. In this case, the medium cooling occurred more rapidly and coal did undergo decantion at the sample proportion as in the glass flasks.

The proportion of germinated seeds was significantly higher in control treatments in $140 \mathrm{~mL}$ glass and plastic flasks, presenting, respectively, 18 and $17 \%$ more germinated seeds in relation to flasks with the lowest concentration of CB. For the $340-\mathrm{mL}$ plastic flasks there was no significant difference between the germination in the control treatment and the lowest concentration of $\mathrm{CB}$. In terms of the proportion of viable seedlings, there was a significant difference only for the plastic flasks, indicating higher values for the control treatment in relation to the lowest concentration of $\mathrm{CB}$ added to the culture medium (Figures 1b, 2c).

The analysis of contrasts showed that the flasks which received CB exhibited germination and yield of fresh and dry matter higher in plastic flasks compared to the glass ones, and the yield in smaller plastic flasks is higher when compared to larger ones.

\subsection{Re-cultivation Experiment (replanting)}

The use of $\mathrm{CB}$ as a chemical disinfectant in culture medium to the in vitro re-cultivation was effective in controlling contamination, and with no case for the disinfested culture media with $\mathrm{CB}$ was observed, as well as in the autoclaved media. The increasing concentrations of $\mathrm{CB}$ added to culture media influenced negatively the Cattleya kerri seedlings growth (Figure 2).

The adjusted model, quadratic root, for the number of emissions of new pseudobulbs indicates that from the estimated concentration of $6.25 \mathrm{~mL} \mathrm{~L}^{-1}$ of $\mathrm{CB}$ there was toxic effect for the seedlings (Figure 2a).

Ribeiro et al. (2011) obtained culture media without microbial contamination using concentrations between 30 and $50 \mathrm{mg} \mathrm{L}^{-1}$ of $\mathrm{NaClO}\left(1.02\right.$ and $1.70 \mathrm{~mL} \mathrm{~L}^{-1} \mathrm{CB}$ ), for the in vitro growth of Sequoia sempervirens. In this study, the increase in the concentration of $\mathrm{NaClO}$ provided explants with lower number of sprouts. The explants in culture medium sterilized with concentration between 30 and $40 \mathrm{mg} \mathrm{L}^{-1}$ of $\mathrm{NaClO}\left(1.02\right.$ and $\left.1.36 \mathrm{~mL} \mathrm{~L}^{-1} \mathrm{CB}\right)$ showed a higher number of sprouts, but smaller length of the same in relation to the autoclaved culture medium.

For the number of roots (NR) values significantly lower were found with the increase of CB concentration added to the culture medium. The lowest concentration of $\mathrm{CB}\left(2 \mathrm{~mL} \mathrm{~L}{ }^{-1}\right)$ provided with a greater number of roots, on average 60 per flask (Figure 2b) which, in principle, it is expected that the latter absorb more nutrients available in the culture medium and have a better growth. 
With the increase in the $\mathrm{CB}$ concentrations, there was an increase in the yield of dry matter from aerial parts until the estimated concentration of $9.92 \mathrm{~mL} \mathrm{~L}^{-1}$ (78 $\left.\mathrm{mg} / \mathrm{recipient}\right)$, from which a reduction $(51 \mathrm{mg} /$ recipient) was observed up to the largest concentration used (38 $\mathrm{mL} \mathrm{L}^{-1}$ ) (Figure 2c).

In terms of dry matter yield of roots and total (shoot + roots), linear negative responses were found to the effect of concentrations, being the highest yields estimated equal to 0.141 and $0.218 \mathrm{~g} /$ recipient, for dry matter of roots and total, respectively (Figures $2 \mathrm{~d}, 2 \mathrm{e}$ ), being the lowest concentration of $\mathrm{CB}\left(2 \mathrm{~mL} \mathrm{~L}^{-1}\right)$ added to the culture medium responsible for the highest yield.

The CB spraying on the seedlings resulted in partial necrosis in some leaves. The higher the concentration sprayed, the greater the necrotic severity on leaves, leading some seedlings to death; however, the seedlings that survived, as time went by, produced new leaves. The shoots growth variables, such as the seedlings average height and the number of leaves per flask, were influenced by CB spraying (Figure 3). Increasing the concentration of spraying resulted in lower values for these variables (Figures 3a, 3b). Such results are in accordance with those obtained by Rodrigues et al. (2012) who verified that the length, the production of fresh matter and the number of sprouts of Arundina bambusifolia and Epidendrum ibaguenses were reduced as the CB was sprayed on the nodal segments.

The ratio between root dry matter and shoot $(\mathrm{R} / \mathrm{S})$ decreased as the concentration of $\mathrm{CB}$ in culture medium increased, demonstrating phytotoxic effect of the product regarding the roots production, as already commented (Figure 3c).

The analysis of contrasts showed that there was no significant difference for the variables evaluated, among the flasks with autoclaved and sterilized culture medium with the lowest concentration of $\mathrm{CB}$ added to the culture medium, during the preparation or sprayed over the seedlings during the re-cultivation. When the autoclaved media were compared with the media that received increasing concentrations of $\mathrm{CB}$, significant differences were observed among the variables evaluated, indicating that the seedlings grew more when grown in autoclaved culture medium. Probably, this result is reflecting the toxicity of the highest concentrations of CB added, resulting in lower growth of seedlings.

From the analysis of the aveage contents of nutrients in the seedlings, after five months of re-cultivation, it was observed that the use of $\mathrm{CB}$, in smaller concentrations, results in better nourished seedlings (higher contents) in relation to the ones cultivated in autoclaved culture medium. It was observed that the autoclaved culture media showed firmer consistency when compared to the media with the addition of CB. Apparently, the seedlings grown in culture medium with the lowest concentration of $\mathrm{CB}$ could exploit more efficiently the culture medium and, therefore, absorb more nutrients. Increasing the concentration of CB led the yield of seedlings with lower root system, and therefore they absorb less water and nutrients (Table 1).

According to the contrasts it is possible to infer that the contents of nutrients were significantly higher in seedlings grown in disinfected culture medium with the lowest 
concentration of $\mathrm{CB}$ in relation to the autoclaved culture medium. When the control treatment was contrasted with the average of all treatments with chemically disinfected culture medium, again, for the majority of nutrients, the levels were higher in seedlings grown in medium with $\mathrm{CB}$. Possibly the greatest production in the autoclaved medium in comparison to the media with higher concentrations of $\mathrm{CB}$ caused an effect of dilution of nutrients in the seedlings, as indicated by Marschner (2008).

Table 1. Nutrient contents in Cattleya kerri Brieger and Bicalho seedlings, after five months of recultivation, submitted to autoclaving and different doses of commercial bleach (CB), added to the culture medium (Medium) and sprayed (Spray) on the seedlings.

\begin{tabular}{|c|c|c|c|c|c|c|c|c|c|c|c|c|c|}
\hline \multicolumn{2}{|l|}{ CB } & \multirow{2}{*}{$\mathbf{N}$} & \multirow{2}{*}{$\mathbf{P}$} & \multirow{2}{*}{$\mathbf{K}$} & \multirow{2}{*}{$\mathbf{C a}$} & \multirow{2}{*}{ Mg } & \multirow{2}{*}{$\mathbf{S}$} & \multirow{2}{*}{$\mathbf{F e}$} & \multirow{2}{*}{$\mathrm{Cu}$} & \multirow{2}{*}{$\mathbf{Z n}$} & \multirow{2}{*}{ Mn } & \multirow{2}{*}{ B } & \multirow{2}{*}{ Mo } \\
\hline Medium & Spray & & & & & & & & & & & & \\
\hline $\mathrm{mL} \mathrm{L}^{-1}$ & & & & $-\mathrm{g} \mathrm{k}$ & $g^{-1}$ & & . & & & - $\mathrm{mg} \mathrm{kg}$ & & & \\
\hline Control & & 20,2 & 4,9 & 24,9 & 9,9 & 2,7 & 5,0 & 91,3 & 6,9 & 109,4 & 87,3 & 66,1 & 0,2 \\
\hline 10,0 & 25,0 & 19,6 & 5,7 & 26,4 & 9,1 & 3,0 & 6,7 & 68,3 & 9,1 & 63,4 & 97,9 & 71,9 & 0,9 \\
\hline 10,0 & 75,0 & 17,8 & 5,8 & 26,1 & 9,2 & 3,0 & 6,2 & 61,3 & 8,5 & 76,0 & 94,4 & 71,0 & 0,5 \\
\hline 30,0 & 25,0 & 11,4 & 4,8 & 17,6 & 8,0 & 2,8 & 7,0 & 81,3 & 12,2 & 44,0 & 80,4 & 75,3 & 0,2 \\
\hline 30,0 & 75,0 & 11,5 & 5,4 & 18,5 & 9,0 & 3,2 & 7,3 & 76,2 & 14,1 & 81,5 & 94,1 & 78,2 & 0,4 \\
\hline 20,0 & 12,5 & 16,9 & 5,7 & 25,0 & 10,3 & 3,2 & 6,5 & 67,5 & 10,8 & 93,7 & 94,2 & 73,6 & 0,9 \\
\hline 20,0 & 87,5 & 16,3 & 5,0 & 19,9 & 8,5 & 2,7 & 6,2 & 78,6 & 9,9 & 76,5 & 82,4 & 44,6 & 0,9 \\
\hline 5,0 & 50,0 & 15,3 & 4,1 & 18,6 & 8,1 & 2,6 & 4,2 & 81,9 & 5,6 & 70,4 & 61,0 & 66,6 & 0,2 \\
\hline 35,0 & 50,0 & 10,4 & 4,7 & 20,0 & 11,0 & 3,1 & 7,6 & 112,9 & 7,2 & 71,8 & 99,8 & 95,5 & 1,1 \\
\hline 10,0 & 5,0 & 22,2 & 6,4 & 29,4 & 9,5 & 3,1 & 6,3 & 63,3 & 9,5 & 87,8 & 94,2 & 80,2 & 0,7 \\
\hline 2,0 & 25,0 & 25,4 & 6,9 & 32,7 & 8,4 & 3,2 & 7,0 & 61,6 & 11,3 & 84,0 & 101,3 & 84,3 & 0,8 \\
\hline 30,0 & 95,0 & (1) & 5,2 & 18,0 & 9,9 & 3,2 & 8,0 & 108,1 & 13,7 & 60,1 & 92,4 & 88,2 & 0,5 \\
\hline 38,0 & 75,0 & 14,9 & 6,1 & 24,4 & 8,2 & 2,8 & 11,9 & 99,6 & 13,3 & 49,0 & 98,3 & 97,1 & 2,3 \\
\hline 20,0 & 50,0 & 17,1 & 5,6 & 24,6 & 9,6 & 3,1 & 6,5 & 66,6 & 11,4 & 79,8 & 92,8 & 82,3 & 0,7 \\
\hline 2,0 & 5,0 & 26,0 & 7,1 & 32,5 & 9,2 & 3,3 & 6,6 & 68,5 & 11,8 & 112,9 & 123,7 & 81,0 & 0,7 \\
\hline 2,0 & 95,0 & 24,5 & 7,3 & 31,0 & 9,7 & 3,3 & 7,4 & 73,6 & 12,3 & 107,9 & 123,2 & 89,1 & 0,7 \\
\hline 38,0 & 5,0 & 16,4 & 6,7 & 26,3 & 9,7 & 2,9 & 8,2 & 79,0 & 10,4 & 87,5 & 130,4 & 81,4 & 1,6 \\
\hline
\end{tabular}

(1) There was not enough dry matter to perform analysis. 


\section{Conclusions}

The commercial bleach (CB), as chemical disinfectant, even at lower concentrations, is efficient to control the microbial activity in culture media. $\mathrm{CB}$ has phytotoxic effect on the germination of Laelia tenebrosa Rolfe, however its use in the lower concentration tested, added to the culture medium and sprayed over the seedlings during the re-cultivation, is as efficient as the use of the autoclave and laminar flow chamber. Increasing concentrations of $\mathrm{CB}$ exert a toxic effect on seedlings grown in glass flasks, while in plastic flasks this fact is not evidenced. CB has little influence on the nutritional state of the seedlings.

\section{References}

Anand M, Brar J, Sood A. (2013) In vitro propagation of edible Bambu Bam-busa bambos and assessment of clonal fidelity through molecular markers. J Med Biol Eng 2(4):257-261. http://doi.org/10.12720/jomb.2.4.257-261

Alvarez-Pardo VM, Ferreira AG, Nunes VF (2006) Seed disinfestation methods for in vitro cultivation of epiphyte orchids from Southern Brazil. Hort Bras 24:217-220. http://doi.org/10.1590/S0102-05362006000200019

Batista DS, Dias LLC, Rêgo MMD, Saldanha CW, Otoni WC (2017) Flask sealing on in vitro seed germination and morphogenesis of two types of ornamental pepper explants. Ci Rural 47(3). http://doi.org/10.1590/0103-8478cr20150245

Braga KQ, Coimbra MC, Castro AHF (2015) Germinação in vitro, indução de calos e teores de compostos fenólicos em Pyrostegia venusta (Ker Gawl.) Miers. Acta Scientiarum. BiolScience 37(2):151-158. http://doi.org/10.4025/actascibiolsci.v37i2. 26067

Chen C (2004) Humidity in plant tissue culture vessels. Bioprocess Biosyst Eng 88:231-241. http://doi.org/10.1016/j.biosystemseng.2004.02.007

Demeester JJ, Matthijs DG, Pascat B, Debergh PC (1995) Toward a controllable headspace composition - Growth, development, and headspace of a micropropagated Prunus rootstock in different containers. In Vitro Cell Dev Biol - Plant 31:105-112

Donini LP, Ferreira-Moura I, Guisso AP, Souza JA, Viégas J (2005) Preparo de lâminas foliares de aráceas ornamentais: Desinfestação com diferentes concentrações de hipoclorito de sódio. Arq Inst Biol 72:517-522.

Ferreira LT, Real NC, Pereira JAF, Ulisses C, Willadino L (2016) Germinação in vitro de gongora (Orchidaceae) em meios nutritivos simplificados. Plant Cell Cult Micro 12(1):20-26.

Gonçalves LA, Geraldine RM, Picoli EAT, Vendrame WA, Carvalho CR, Otoni WC (2008) In vitro propagation of Herreria salsaparilha Martius (Herreriaceae) as affected by different sealing materials and gaseous exchanges. Plant Cell 92:243-250

Jackson ML (2005) Soil chemical analysis. Advanced course, $2^{\mathrm{a}}$ ed. Madison

Kishor R, Khan PSSV, Sharma GJ (2006) Hybridization and in vitro culture of an orchid hybrid Ascocenda 'Kangla'. Sci Hort 108:66-73. http://doi.org/10.1016/j.scienta.2005.12.004 
Leite RA (1984) Uso de matrizes experimentais e de modelos estatísticos no estudo do equilíbrio fósforo-enxofre na cultura de soja em amostras de dois Latossolos de Minas Gerais. Masters dissertation. Universidade Federal de Viçosa, Viçosa, Brazil

Lima JD, Moraes WS (2006) Controle de bactérias contaminantes em explantes de bananeira (Musa AAA cv. caipira). Pesq Agropec Bras 36:181-186

Marino G, Berardi G (2004) Different sealing materials for Petri dishes strongly affect shoot regeneration and development from leaf explants of Quince 'BA 29'. In Vitro Cell Dev Biol Plant 40:384-388. http://doi.org/10.1079/IVP2004550

Marschner H (2008) Mineral nutrition of higher plants. Academic Press, London

Moraes CP, Diogo JA, Canabrava RI, Pedro NP, Furtado ALF, Marteline MA (2010) Desenvolvimento in vitro de Dendrobium nobile Lind. (Orchidaceae) em recipientes de diferentes volumes. Rev Bras Bio 8:225-228.

Nogueira, M. C. S. (2004). Orthogonal contrasts: definitions and concepts. Scien Agri, 61(1):118-124. http://doi.org/10.1590/S0103-90162004000100020

Pereira GA, Boliani AC, Correa LS (2015) Disinfestation and in vitro establishment of Thap maeo (AAB subgroup) banana explants submitted to chlorine concentrations. Comun Sci 6(4):412. http://doi.org/sci-hub.cc/10.14295/cs.v6i4.712

Pierik RLM (1987) In vitro culture of higher plants: closure of test tubes and flasks. Matinus Nijhoff Publishing, Netherlands

Pierik RLM (1997) In vitro culture of higher plants. Springer Science \& Business Media, Netherlads

Pinheiro MVM, Martins FB, Xavier A, Otoni WC (2013) Gas exchange affects in vitro morphogenesis of two olive cultivars (Olea europaea L.). Rev Árvore 37(1): 19-29. http://doi.org/10.1590/S0100-67622013000100003

Ray SS, Ali MN, Mukherjee S, Chatterjee G, Banerjee M (2017) Elimination and molecular identification of endophytic bacterial contaminants during in vitro propagation of Bambusa balcooa. World J Microbiol Biotechnol 33(2):31. http://doi.org/10.1007/s11274-016-2196-Z

Rego-Oliveira LV, Faria RT (2005) In vitro propagation of Brazilian orchids using traditional culture media and commercial fertilizers formulations. Acta Sci, Agron 27:1-5

Ribeiro APO, Picoli EAT, Lani ERG, Vendrame WA, Otoni WC (2009) The influence of flask sealing on in vitro morphogenesis of eggplant (Solanum melongena L.). In Vitro Cell Dev Biol - Plant 45:421-428

Ribeiro JM, Teixeira SL, Bastos DB (2011) Cultivo in vitro de Sequoia sempervirens L. em meio de nutritivo esterilizado com hipoclorito de sódio. Ci Flor 21:77-82

Rodrigues DT, Novais RF, Alvarez V VH, Dias JMM, Villani EMA, Otoni WC (2011) In vitro germination of Cattleya intermedia $\mathrm{R}$. Graham by means of chemical disinfection and 
without laminar flow. Propag Ornam Plants 11:119-124

Rodrigues DT, Novais RF, Venegas VHA, Dias JMM, Otoni WC, Villani EMDA (2013) Chemical sterilization in in vitro propagation of Arundina bambusifolia Lindl. and Epidendrum ibaguense Kunth. Rev Ceres 60(4):447-451.

http://doi.org/10.1590/S0034-737X2013000400001

Rodrigues M, Costa TH, Festucci-Buselli RA, Silva LC, Otoni WC (2012) Effects of flask sealing and growth regulators on in vitro propagation of neem (Azadirachta indica A. Juss.). In Vitro Cell Dev Biol - Plant 48(1):67-72. http://doi.org/10.1007/s11627-011-9398-8

Santos AF (2009) Composição mineral do meio de cultura para crescimento in vitro de Cattleya walkeriana $\times$ self. Master dissetation. Universidade Federal de Viçosa, Viçosa, Brazil

Sharma V (2016) Orchid propagation for conservation and commercialization a study in vitro. Panjab University, India

Srivastava AK, Yadav SK, Mishra RK., Diengdoh LC, Rai R, Bag TK (2016) Effect of different test tube closure methods on growth and development of potato cultivars. Int J Adv Agric Sci Technol 8(1):58-61. http://doi.org/10.5958/2394-4471.2016.00012.5

Teixeira SL, Souza RTS, Teixeira MT (2005) Esterilização de meios nutritivos para cultura de tecidos vegetais em forno de microondas. Rev Ceres 52:499-507

Thomas TD (2008) The role of activated charcoal in plant tissue culture. Biotechnol Adv 26:618-631. http://doi.org/10.1016/j.biotechadv.2008.08.003

Torres GRC, Houllou LM, de Souza RA (2016) Control of contaminants during introduction and establishment of Bambusa vulgaris in vitro. $\mathrm{R}$ Biotechnol 7:257. http://doi.org/10.19071/rib.2016.v7.3056

Venturieri GA, Venturieri AR, Leopoldo G (2013) Sterilization of culture media for orchids using a microwave oven. In Vitro Cell Dev Biol - Plant 49(2):137-144. http://doi.org/10.1007/s11627-012-9470-z

Vogel AI (1992) Análise química quantitativa. $5^{\text {a }}$ ed. Rio de Janeiro, Guanabara Koogan

Yanagawa T, Nagai M, Ogino T, Maeguchi R (1995) Application of disinfectants to orchid seeds, plantlets and media as a means to prevent in vitro contamination. Lyndleyana 10:33-36

Zobayed SMA (2006) Aeration in plant tissue culture. In: Dutta Gupta S, Ibaraki Y (eds) Plant tissue culture engineering, Springer, Netherlands, pp 313-327.

\section{Copyright Disclaimer}

Copyright for this article is retained by the author(s), with first publication rights granted to the journal.

This is an open-access article distributed under the terms and conditions of the Creative Commons Attribution license (http://creativecommons.org/licenses/by/4.0/). 